Article

\title{
Academic Collaboration in Entrepreneurship Research from 2009 to 2018: A Multilevel Collaboration Network Analysis
}

\author{
Rui Song ${ }^{1}$, Hao Xu ${ }^{1,2,3, *}$ and Li Cai ${ }^{2}$ \\ 1 College of Computer Science and Technology, Jilin University, Changchun 130012, China; \\ ruisong18@mails.jlu.edu.cn \\ 2 School of Management, Jilin University, Changchun 130012, China; cli@jlu.edu.cn \\ 3 Key Laboratory of Symbolic Computing and Knowledge Engineering of Ministry of Education, \\ Jilin University, Changchun 130012, China \\ * Correspondence: xuhao@jlu.edu.cn; Tel.: +86-133-0431-0608
}

Received: 2 September 2019; Accepted: 17 September 2019; Published: 20 September 2019

\begin{abstract}
Entrepreneurship research is widely regarded as an important basis for competitive advantage in a rapidly changing international business environment, enhancing capacities for sustainable business growth, economic activity, and the wealth of nations. In recent years, international cooperation has been considered to be one of the key factors promoting the sustainable development of entrepreneurial research. However, the evolution of the cooperative network of entrepreneurial research and the relationship between international cooperation and entrepreneurial research performance has not received the attention of most researchers. Therefore, we used a multilevel collaborative analysis method, i.e., country, city, institution and scholar, analyzing 2037 studies in this area from 2009 to 2018 from the Business Source Complete database by collaboration network analysis and bibliometric analysis. Our study tracked the evolution and cooperation trends in entrepreneurship research and detailed characteristics of international academic cooperation over the past decade, and we found the following: (1) The four types of cooperative networks have evolved over time, and generally conform to the distribution characteristics of the core periphery; cities, institutions, and researchers from central countries such as the United States, the United Kingdom, Canada, France and Germany occupy central positions in cooperation; they are scale-free networks and subject to the principle of priority connection. (2) The evolution of cooperative networks at different levels are non-conformal, there is a subtle relationship between micro-networks that can explain the distribution and changes in macro-networks. (3) International academic cooperation can promote the performance of entrepreneurial research, and cooperation has become the main theme of entrepreneurial research. These findings can help researchers to better study cooperative relationships in entrepreneurship research. Moreover, they can provide entrepreneurial decision support for national and local governments and contribute to the sustainable development of entrepreneurial research.
\end{abstract}

Keywords: collaborative network analysis; entrepreneurship research; bibliometric analysis; social network analysis; sustainable entrepreneurship

\section{Introduction}

Entrepreneurship is regarded as a powerful tool for social and economic transformation, innovation and entrepreneurship can not only drive the economy, but also provide more jobs [1]. Since 1980, entrepreneurship has increasingly been recognized as a key factor in regional economic development, especially from a macroeconomic perspective [2]. Entrepreneurial knowledge and innovation 
capabilities play an essential role in recognizing opportunities for sustainable development [3]. Although about two generations ago, scholarly research on entrepreneurship was rare and almost nonexistent [4], this area has become one of the most important, dynamic and relevant areas of management and social sciences [5]. In recent years, the growth of entrepreneurship research has brought lots of research works. Bibliometric analysis is one of the most suitable methods for analyzing these research works [6]. Some research focuses on specific sub-fields of entrepreneurship research, such as international entrepreneurship, social entrepreneurship, entrepreneurship education and rural entrepreneurship [7-10]. Other research pays attention to the fields most related to entrepreneurship research [11,12]. Meanwhile, the importance of the network in promoting entrepreneurial activities has also been extensively studied [13]. Co-author networks and co-citation networks are often explored to discover partnerships and knowledge structures of entrepreneurship research [14,15]. Bibliometric analysis and network analysis of entrepreneurship research have made a great contribution to illuminating the dynamics of the types of methodologies and topics, such as historical accounts and policy-related issues as well as providing an analysis of publication trends for authors, journals and patterns of research [10]. At the same time, the analysis and research of academic research results is conducive to strengthening the transformation of academic achievements and knowledge capitalization. Governments are also encouraging this development strategy to transform academics' findings into economic results, to improve the sustainability of entrepreneurial research [16].

With the development of information technology and the acceleration of globalization, the importance of international academic cooperation has been recognized theoretically and practically. Collaboration generates more knowledge, which, in return, leads to new ideas and academic output [17]. Research collaboration between authors from different places can promote advances in research results and methods in related fields, leading to more effective development outcomes [18]. In addition, academic cooperation can promote the improvement of research quality, improve the efficiency of scientific production, and promote breakthroughs in a shorter period of time $[19,20]$. However, few bibliometric studies of entrepreneurship focused on international academic collaboration networks have been reported in literature, especially for structural characteristics and evolutionary regulation of international collaboration network for entrepreneurship research in the past 10 years. Moreover, there has been little in-depth research on cooperation between scholars, institutions, cities and countries and a lack of discussion on the relationship between international collaboration and entrepreneurial research performance.

Therefore, in order to study the detailed characteristics of international academic cooperation in the field of entrepreneurial research and to examine the regional distribution and evolution of academic cooperation at different levels, we collected relevant literature on entrepreneurship research from 2009 to 2018, and explored the overall development of entrepreneurship research and changes from different perspectives. Bibliometric analysis and collaborative network analysis were applied to the analysis process; these allow us to understand the academic cooperative development trend of entrepreneurial research more clearly, and also have good control over the research hotspots in the current field, as well as experts and institutions. In addition, the impact of international academic collaboration on the performance of entrepreneurship research has also been explored. This helps promote international academic collaboration, accelerate the transformation of academic outcomes, and assists industry stakeholders in deeper exploration of the sustainability of entrepreneurial research.

The rest of the paper is structured as follows: In Section 2, we introduce the data sources and methods of analytics. In Section 3, we explore the academic cooperation networks of countries, cities, institutions, and scholars, as well as their evolution rules, and study the relationship between performance and international collaboration. Section 4 summarizes the whole paper and presents the conclusions. 


\section{Data and Methods}

\subsection{Data}

Before collecting data, we had a discussion with the author, Professor Li Cai, and her research group and identified the following keywords in the field of entrepreneurship: entrepreneur, new venture, emerging venture, founder, spin-off, start-up, and venture capital, which were summarized from previous studies [21-23]. Database coverage is an essential component of a bibliometric study. Once a discipline or other variable is chosen for study by an investigator, the database that will be used must contain the scholarly literature represented in that discipline [24]. We searched for these keywords in Business Source Complete. Business Search Complete is an essential tool for business students, which covers all disciplines of business, including marketing, management, accounting, banking finance and more. Link: https://www.ebsco.com/products/research-databases/business-sourcecomplete. We selected papers with these keywords in specific fields, such as in the title, or abstract. After summarizing and screening, we acquired 2037 papers from the search results. Table 1 shows the number of total papers and international collaboration papers for every year.

Table 1. Number of total papers and international collaboration papers every year.

\begin{tabular}{ccccccccccc}
\hline & $\mathbf{2 0 0 9}$ & $\mathbf{2 0 1 0}$ & $\mathbf{2 0 1 1}$ & $\mathbf{2 0 1 2}$ & $\mathbf{2 0 1 3}$ & $\mathbf{2 0 1 4}$ & $\mathbf{2 0 1 5}$ & $\mathbf{2 0 1 6}$ & $\mathbf{2 0 1 7}$ & $\mathbf{2 0 1 8}$ \\
\hline Number of papers & 175 & 170 & 182 & 193 & 218 & 211 & 201 & 237 & 226 & 224 \\
Number of collaboration papers & 105 & 112 & 133 & 100 & 145 & 131 & 137 & 154 & 172 & 185 \\
Percentage (\%) & 60.0 & 65.9 & 73.1 & 51.8 & 66.5 & 62.1 & 68.2 & 65.0 & 76.2 & 82.6 \\
\hline
\end{tabular}

In order to ensure the validity of the data, these articles were all selected from 12 journals below, which have been selected as the scope of research by previous entrepreneurial studies [21,22]. The numbers of articles published in each journal and the corresponding impact factor by 2018 are shown in Table 2.

Table 2. Journals with related publications and their impact factors.

\begin{tabular}{ccc}
\hline Journal & Number & Impact Factor \\
\hline Entrepreneurship: Theory \& Practice & 415 & 6.193 \\
Small Business Economics & 546 & 3.555 \\
Academy of Management Review & 51 & 10.632 \\
Journal of Business Venturing & 357 & 6.333 \\
Journal of Management Studies & 87 & 5.839 \\
Management Science & 72 & 4.219 \\
Strategic Management Journal & 99 & 5.572 \\
Administrative Science Quarterly & 22 & 8.042 \\
Strategic Entrepreneurship Journal & 178 & 2.956 \\
Academy of Management Journal & 64 & 7.191 \\
Organization Science & 81 & 3.257 \\
Journal of Management & 65 & 9.095 \\
\hline
\end{tabular}

\subsection{Methodology}

Since the 1980s, entrepreneurship has rapidly entered the field of mainstream management research. The enthusiasm for entrepreneurship research has been continuously rising, and the research literature has become increasingly rich [25]. The increase in relevant literature provides the possibility for studying the cooperative relationships of entrepreneurship research based on the literature. In this paper, a variety of methods was used to study international academic cooperation and distribution of entrepreneurship research, including bibliometric analysis and social network analysis.

Bibliometric analysis is one of the most important tools for exploring libraries and information science [26]. It is a form of scientific publication analysis which examines publications from an objective, 
quantitative perspective [27]. There are two main approaches to exploring research in bibliometric analysis, performance analysis and scientific mapping [28]. In this paper, the former is used to evaluate the center of collaboration, and the latter is used to show the evolution of cooperative networks.

Social network analysis (SNA) is the process of investigating social structures through the use of networks and graph theory [29]. The main problem that social network research solves is how autonomous individuals can combine in order to create enduring, functioning societies [30]. In the study of social networks, the conventional measures are the degree centrality, betweenness centrality, and closeness centrality [18]. However, because of the complexity of the international cooperative network, simple centrality research is not enough. A simple visualization of the network data can be illuminating, but it is not sufficiently precise to serve as an adequate basis for scientific work [31]. We thus use some indices to measure the importance of the nodes in terms of different networks. At the same time, some special structures in the network graph are explored, such as communities, isolated vertices [30], and so on.

If two scholars collaborate on one or more papers, then they have a cooperative relationship in the network [32]. International collaboration represents relationships at a macro level. Research on the international academic cooperation network can discover the position of each country in its cooperation, check the closest cooperation relationship, and promote international academic communication and cooperation. We utilized the collaborative breadth index (CBI) and collaborative depth index (CDI) for the country-level analysis [18]. The CBI is the breadth of international cooperation; the more centrality a country has, the more partnerships it has. The CDI shows how closely a country works with other countries; the formula for the CDI is defined as follows:

$$
\mathrm{CDI}_{\mathrm{i}}=\frac{\sum_{\mathrm{i}}^{\mathrm{N}} \mathrm{M}_{\mathrm{i}, \mathrm{j}}}{\mathrm{DC}_{\mathrm{i}}}
$$

where $\mathrm{M}_{\mathrm{i}, \mathrm{j}}$ indicates the number of collaborative papers between countries $\mathrm{i}$ and $\mathrm{j}, \mathrm{N}$ stands for all states that exist, and $\mathrm{DC}_{\mathrm{i}}$ is the degree centrality of node $i$.

As for the city level, we studied the characteristics at the regional level which directly explain the distribution of the international academic cooperation, and as a bridge between institutions and countries. Institutions are the academic research centers of a city, and a university is often responsible for all of the academic output of a city. As for the scholars, we used the Paper impact index (PII) and Author contribution index (ACI) in our research [33]. The formulae are defined as follows:

$$
\begin{gathered}
\mathrm{PII}=\sum_{\mathrm{i}}^{\mathrm{n}} \mathrm{IF}_{\mathrm{i}} \\
\mathrm{ACI}=\mathrm{A}_{1}+0.5 \mathrm{~A}_{2}+0.25 \mathrm{~A}_{3}+0.125 \mathrm{~A}_{4}+\ldots+0.125 \mathrm{~A}_{\mathrm{n}}
\end{gathered}
$$

where $n$ represents all of the papers published by a scholar, $\mathrm{IF}_{\mathrm{i}}$ is the Impact Factor of the journal for the past five years, and $A_{i}$ represents the number of papers published by scholars as the $i$-th author. Scholars with high scores in both indexes are considered to be those leading the academic research in their fields. Their research methods reflect the current mainstream research methods, and their research topics represent current hot issues. The framework describing the above four levels of cooperation is shown in Figure 1. 


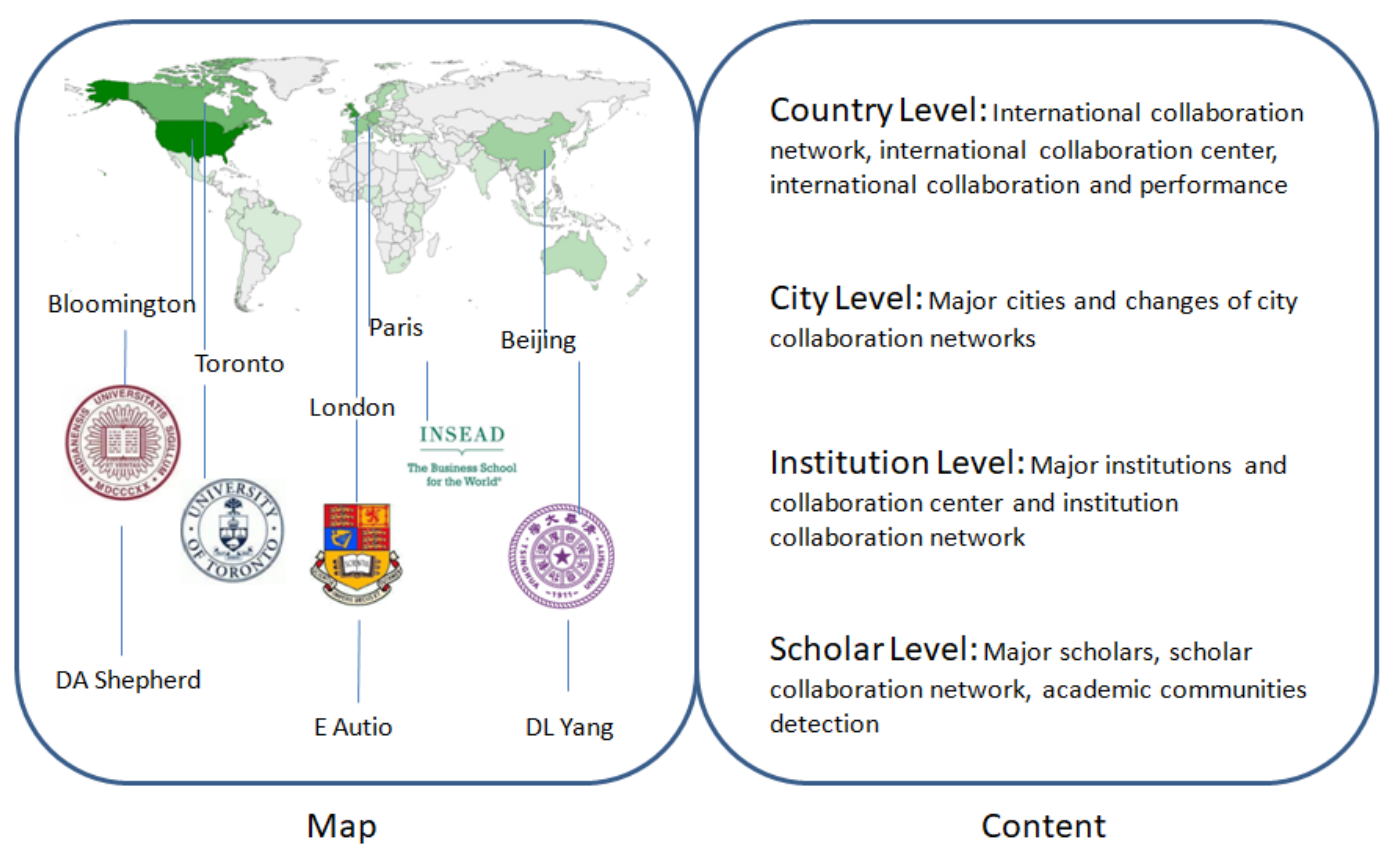

Figure 1. Different levels of cooperation.

\section{Results and Discussion}

\subsection{Country Level}

First of all, the countries to which scholars belong were examined. Figure 2 shows the distribution of the entrepreneurial papers in our dataset around the world. The deeper the color, the larger the number of papers published. It can be clearly seen that the United States maintains an absolute advantage in the number of articles published. The United Kingdom, Canada, and some European countries also have large contributions.

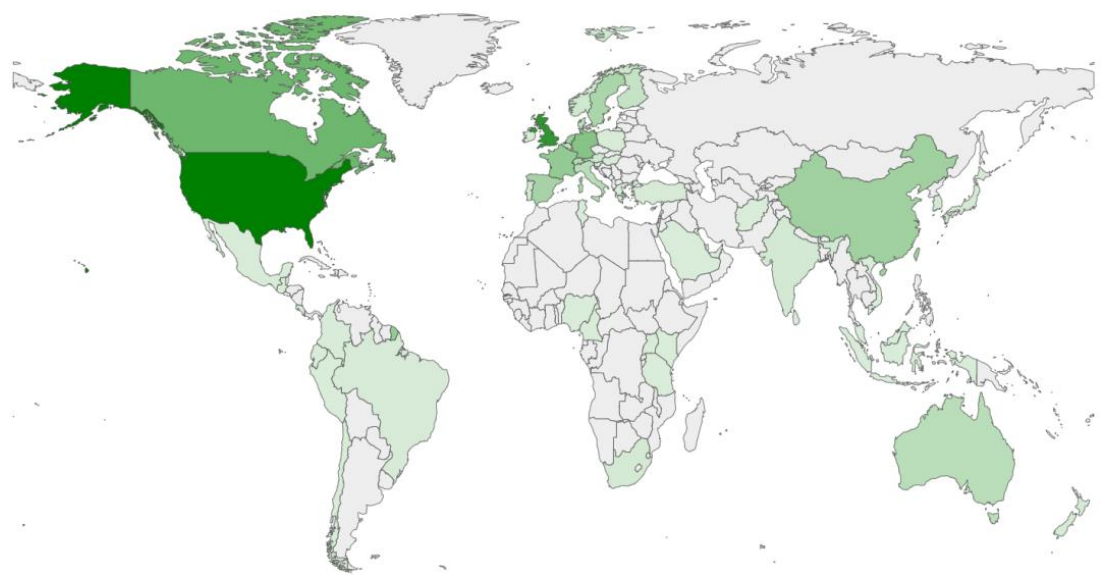

Figure 2. A visualization of dominant countries in terms of papers published annually.

In order to explore the degree of cooperation at different national levels and the general trend of change, two sections of international academic cooperation networks were studied according to international cooperation separated by 2013 (Figure 3). The size of the node indicates the number of articles published, and the thickness of the edge indicates the number of instances of cooperation [34].

Overall, the international academic cooperation network has an obvious core-periphery feature, a few countries occupied most partnerships. The total number of collaborations increased over time, and the breadth of collaboration increased. High-yielding countries such as the United States, Canada, 
and the United Kingdom have remained stable, but some other countries are rising. Some developed European countries, such as France, Germany, Finland, Denmark, Sweden, Italy, and Spain show good performance; at the same time, Singapore and China are also showing a positive development stance. The United States has the most extensive cooperative relationships; it prefers to cooperate with Canada and some European countries. The United Kingdom has the second highest number of co-authored papers; it prefers to work with other European countries. It can be inferred that geographical location will affect cooperative relationships to a certain extent.

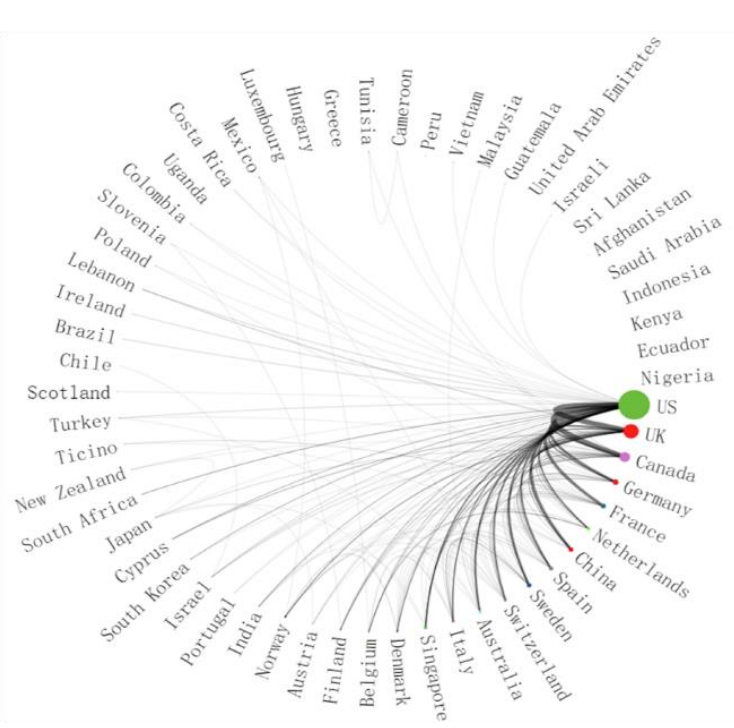

(a)

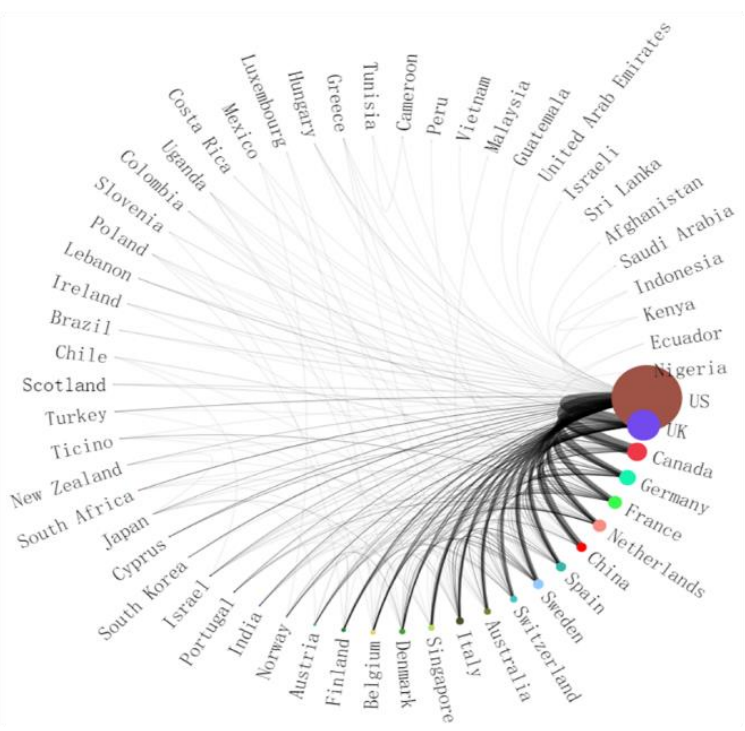

(b)

Figure 3. Evolution of international collaboration networks: (a) 2009-2013; (b) 2009-2018.

There are some pendant vertices in international academic cooperation; each of them has only one partnership with others. All pendant vertices and corresponding partners are shown in Table 3. The United States has the most extensive partnerships; it connects with nine pendant vertices. In terms of the amount of cooperation, all of the pendant vertices are related to cooperation with the unpopular, which represents a weak tie. Contrary to a strong tie, a weak tie occupies a more important position in cross-border information exchange, and the efficiency of information exchange is also higher [35].

Table 3. All pendant vertices in international collaboration networks.

\begin{tabular}{ccc}
\hline Pendant Vertex & Partner & Collaboration Number \\
\hline Brunei & USA & 1 \\
Guatemala & USA & 1 \\
United Arab Emirates & USA & 1 \\
Afghanistan & USA & 1 \\
Saudi Arabia & USA & 1 \\
Sri Lanka & USA & 1 \\
Nigeria & USA & 1 \\
Peru & Spain & 1 \\
Malaysia & Australia & 1 \\
\hline
\end{tabular}

Next, the CBI and CDI were used to reveal the breadth and depth of the collaborative relationships of different countries in two time spans. Figure 4 shows that most countries are migrating to the right, which indicates that almost all countries are actively expanding the scope of their cooperation, but different countries show varying degrees of change. The United States and the United Kingdom continue leading international cooperation. Canada, France, the Netherlands, Germany, and other 
European countries are in a similar state; they have quite a wide range of cooperation, and although they have not established strong partnerships like the United States and the United Kingdom, they also have good performance. China and Singapore have deepened their partnerships based on original partnerships.

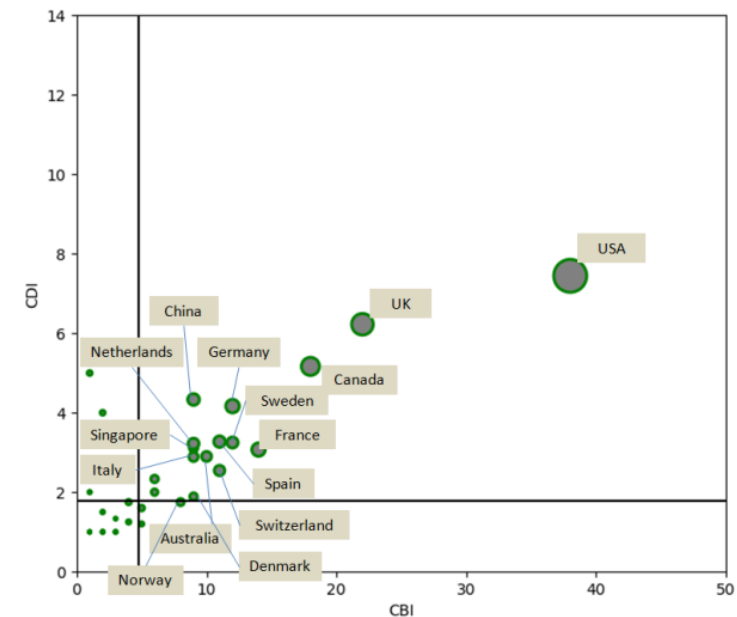

(a)

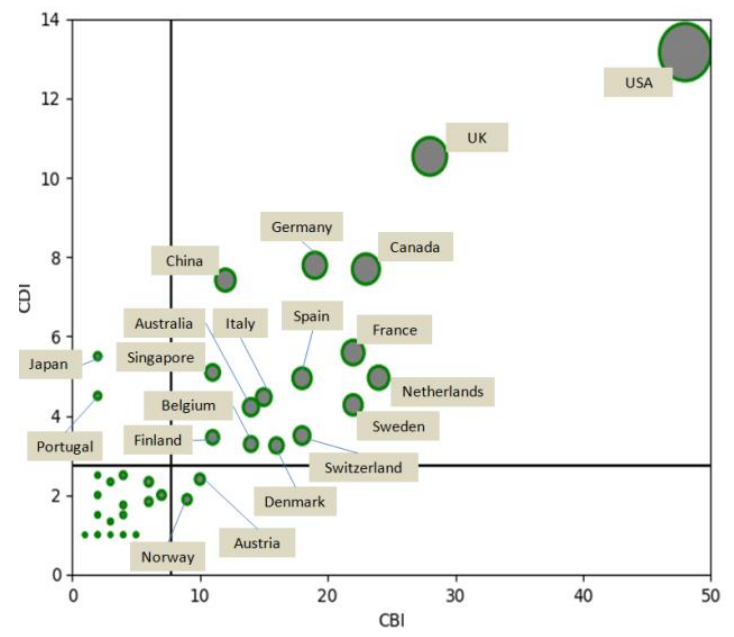

(b)

Figure 4. Collaborative breadth indices (CBIs) and collaborative depth indices (CDIs): (a) 2009-2013; (b) 2009-2018.

Collaboration increases the research output [36]. The quantitative relationship between international cooperation and entrepreneurial research performance was studied. The number of published academic papers can measure performance and explore the impact of international collaboration on performance [37]. In addition, the impact factor is also used to measure the quality of published articles. When data are not bivariate normal, the Spearman correlation coefficient is usually used as a correlation index [38]. The CBI and CDI were used to represent the degree of international cooperation and the number and quality of published papers were used to represent performance. The analysis results in Table 4 show a strong positive correlation between international cooperation and the performance of entrepreneurial research, which indicates that international cooperation can effectively promote entrepreneurial research.

Table 4. Spearman correlation coefficients between cooperation and performance.

\begin{tabular}{ccc}
\hline & CBI & CDI \\
\hline Number of papers & 0.936 & 0.953 \\
Paper quality & 0.833 & 0.878 \\
\hline
\end{tabular}

Figure 5 shows the relevance more intuitively between international academic collaboration and performance. Each point in the figure represents a country. The upper part shows the promotional effect of the CBI and CDI on the number of published papers, and the lower part presents the sum of the impact factors of the journals in which each paper was published in each country. The linear regression clearly fits the positive correlation between cooperation and performance. The blue shading indicates that the fitted line floats within a 95\% confidence interval. The results give recommendations for international collaboration in order to increase the performance of entrepreneurial research. 


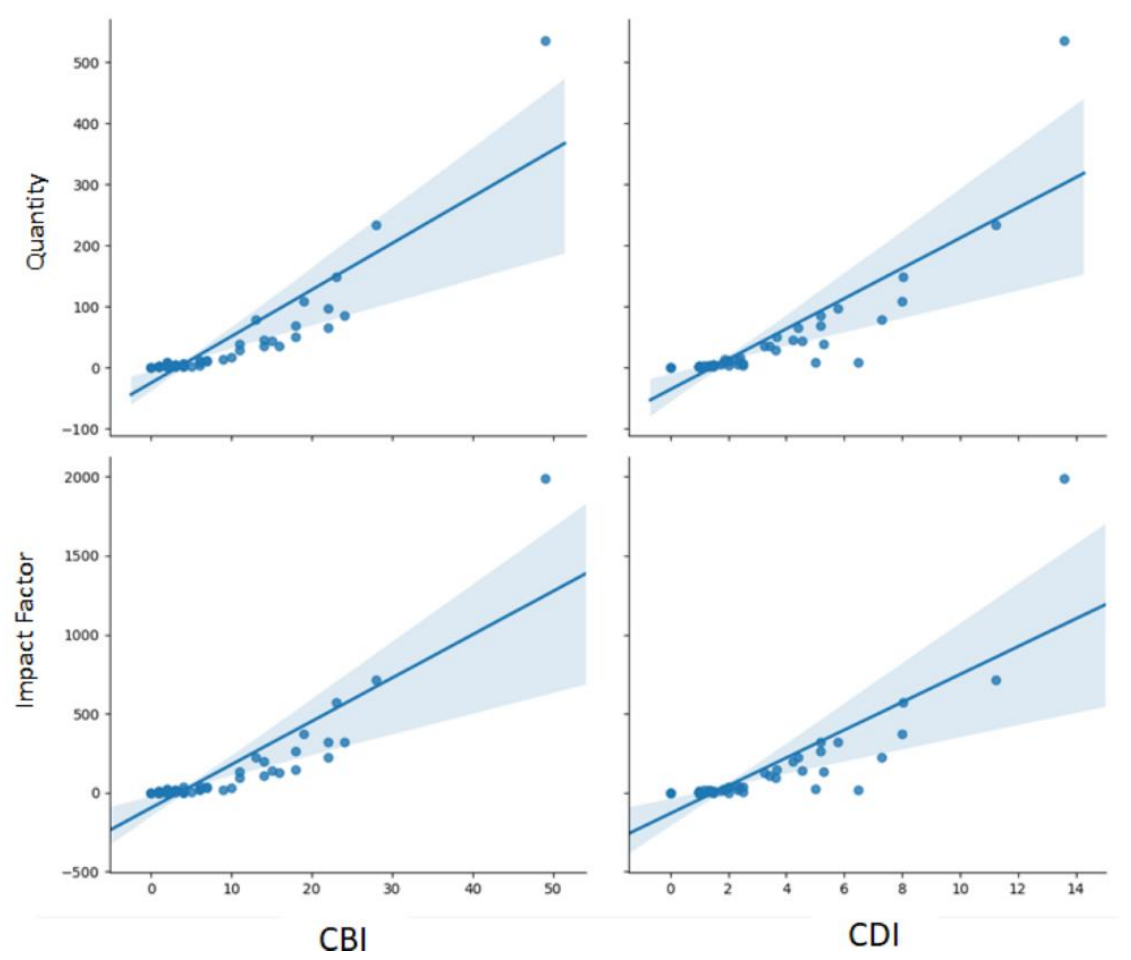

Figure 5. Linear regression of the number and quality of published articles by the CBI and CDI (confidence $=95 \%$ ).

\subsection{City Level}

With the development of science and technology becoming an important regional economic unit of a country, the status of cities has become increasingly prominent [39]. As shown in the analysis in the previous section, international academic cooperation has changed dynamically over time. As the next level of the country, research at the city level can directly explain this phenomenon. Therefore, we examined the details of the cities where the organization are located. According to our dataset, 595 cities from different countries participated in international academic collaboration. As shown in Figure 6, the network of cooperation between the cities also presents the characteristics of the core periphery. The performance of American cities is outstanding, which directly explains the central position of the United States in international cooperation. London and Bloomington lead the academic collaboration, but some cities from other countries also have pretty good performance. Munich, Rotterdam, Copenhagen, Stockholm, Milan, Amsterdam, Toronto, Paris, Beijing, Hong Kong also occupy important positions in academic collaboration. 


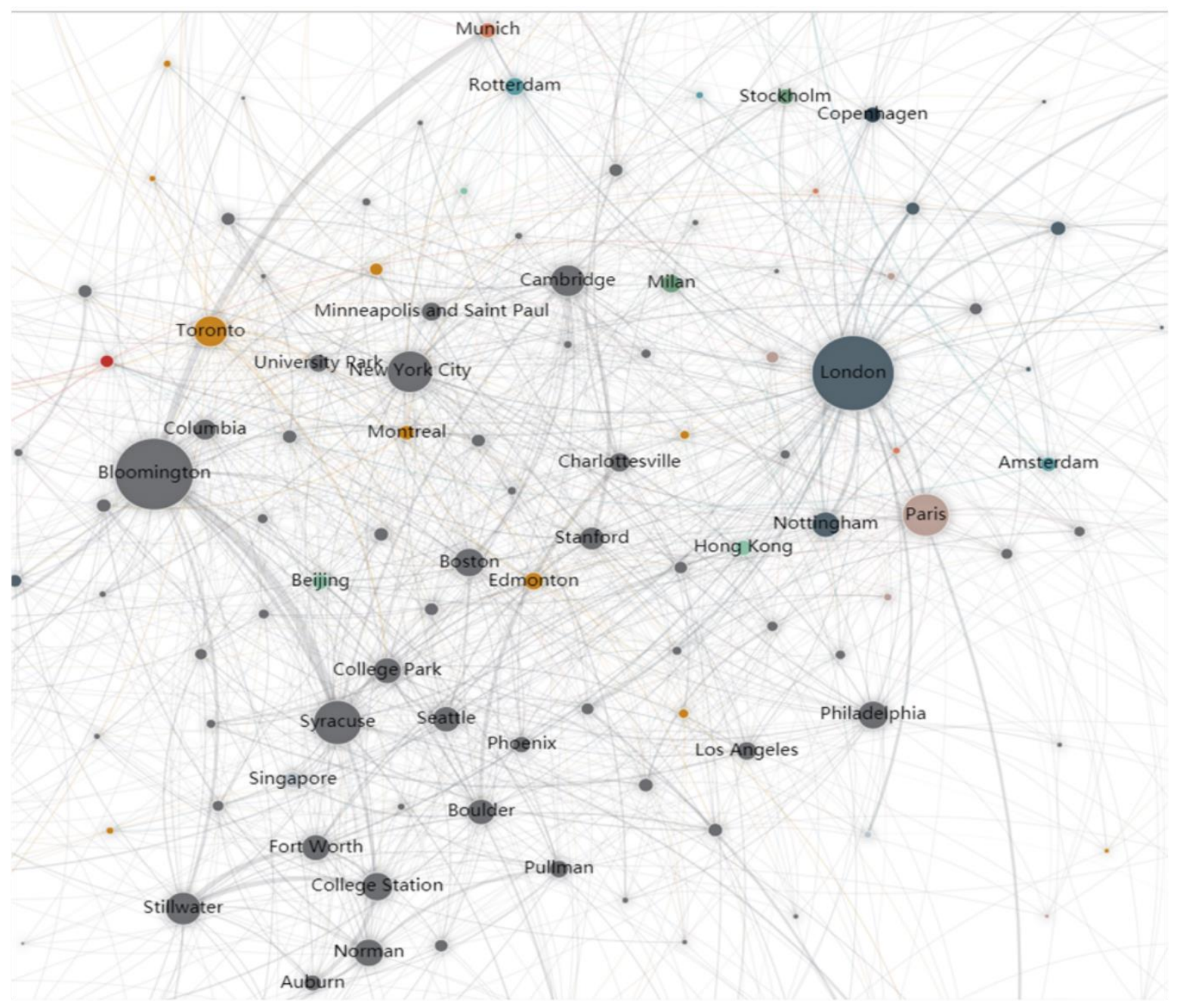

Figure 6. Collaboration network among cities in 2018.

In order to understand how the cooperation network between cities has evolved more clearly, the collaborative networks for different years were analyzed in Figure 7. The central node has continued developing and that the density of cooperation has increased. At first, there were only two central cities, i.e., London and Bloomington, from 2009 to 2010, but in the next two years, New York City and Syracuse in the United States and Paris in France gradually developed into central cities. During that time, Bloomington and Syracuse established a strong relationship that has since continued. Subsequently, the central city continued increasing in influence and established cooperative relationships with the original central city. Cities in other countries, such as Toronto, were booming. This follows the rule that new vertices in the network are preferentially connected to well-connected vertices [40]. This law also appeared in the network of institutions and researchers. 


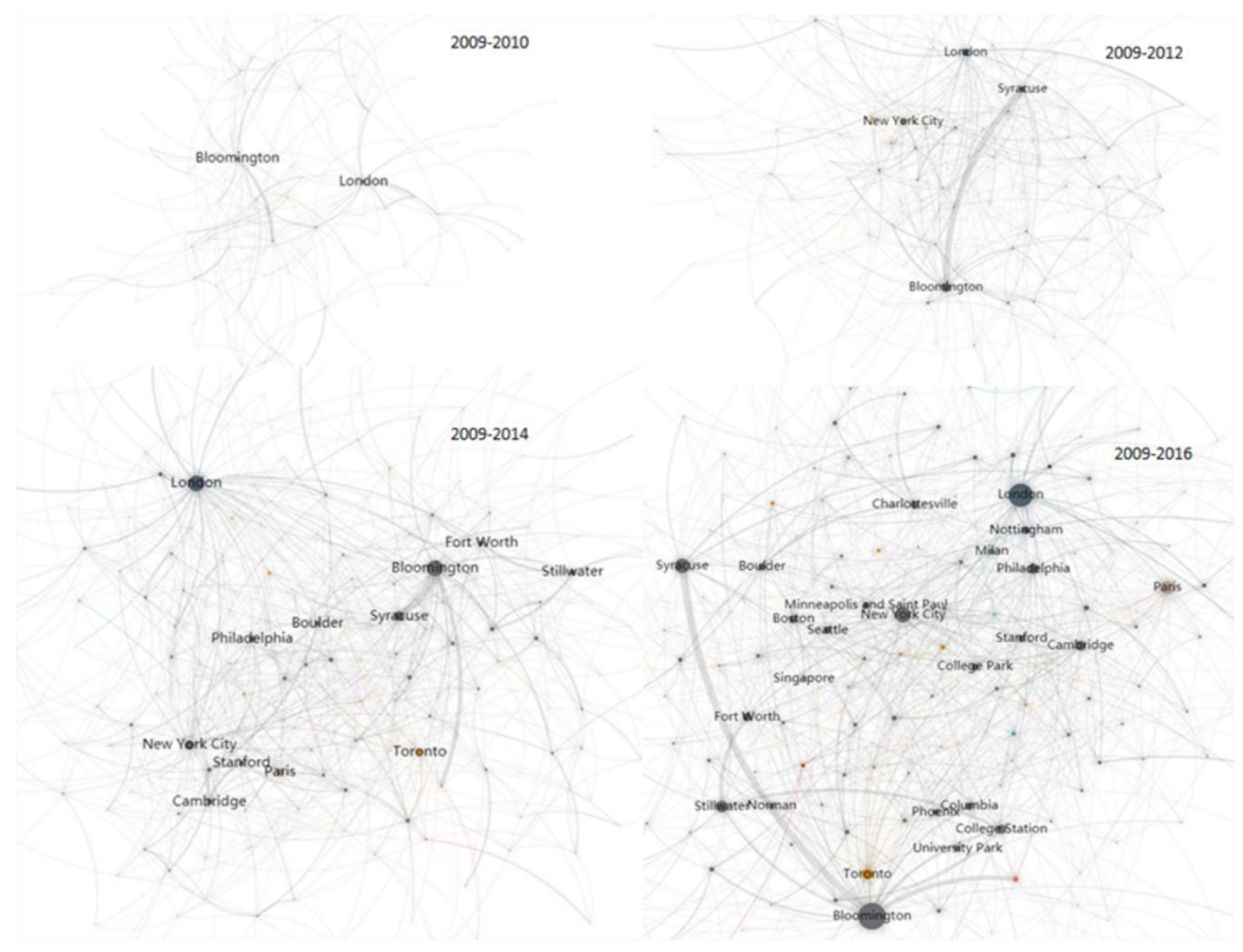

Figure 7. Evolution of collaboration networks among cities.

In order to further explore the distribution of these major cities, we ranked the importance of the cities according to the number of collaborative papers in five time periods (Table 5). In general, the regional development of the entrepreneurial field is also undergoing unbalanced and dynamic change. Bloomington and London ranked highest because they were the earliest collaboration centers. As time goes on, Syracuse, Cambridge, and New York City in the United States and Paris in France appear on the table with their rankings gradually rising. Capitals of some countries have developed rapidly in recent years and have become central cities, such as Amsterdam, Toronto and Copenhagen. Their emergence indicates that more and more cities from different countries are involved in entrepreneurial research, and international cooperation is becoming increasingly popular. 
Table 5. Central cities evolution over time.

\begin{tabular}{|c|c|c|c|c|c|}
\hline Year & 2009-2010 & 2011-2012 & 2013-2014 & 2015-2016 & 2017-2018 \\
\hline 1 & $\begin{array}{l}\text { Bloomington, } \\
\text { US }\end{array}$ & $\begin{array}{l}\text { Bloomington, } \\
\text { US }\end{array}$ & $\begin{array}{l}\text { London, } \\
\text { UK } \uparrow\end{array}$ & $\begin{array}{l}\text { Bloomington, } \\
\text { US } \uparrow\end{array}$ & $\begin{array}{c}\text { London, } \\
\text { UK } \uparrow\end{array}$ \\
\hline 2 & $\begin{array}{l}\text { London, } \\
\text { UK }\end{array}$ & $\begin{array}{l}\text { London, } \\
\text { UK }\end{array}$ & $\begin{array}{l}\text { Philadelphia, } \\
\text { US } \uparrow\end{array}$ & $\begin{array}{l}\text { London, } \\
\text { UK } \downarrow\end{array}$ & $\begin{array}{c}\text { Bloomington, } \\
\text { US } \downarrow\end{array}$ \\
\hline 3 & $\begin{array}{l}\text { Paris, } \\
\text { France }\end{array}$ & $\begin{array}{c}\text { Syracuse, } \\
\text { US } \uparrow\end{array}$ & $\begin{array}{c}\text { Bloomington, } \\
\text { US } \downarrow\end{array}$ & $\begin{array}{l}\text { Milan, } \\
\text { Italy * }\end{array}$ & $\begin{array}{c}\text { Paris, } \\
\text { France } \uparrow\end{array}$ \\
\hline 4 & $\begin{array}{c}\text { New York City, } \\
\text { US }\end{array}$ & $\begin{array}{c}\text { Paris, } \\
\text { France } \downarrow\end{array}$ & $\begin{array}{l}\text { Paris, } \\
\text { France }\end{array}$ & $\begin{array}{l}\text { Philadelphia, } \\
\text { US } \downarrow\end{array}$ & $\begin{array}{c}\text { Cambridge, } \\
\text { US } \uparrow\end{array}$ \\
\hline 5 & $\begin{array}{l}\text { Columbia, } \\
\text { US }\end{array}$ & $\begin{array}{c}\text { New York City, } \\
\text { US } \downarrow\end{array}$ & $\begin{array}{c}\text { New York City, } \\
\text { US }\end{array}$ & $\begin{array}{c}\text { Cambridge, } \\
\text { US } \uparrow\end{array}$ & $\begin{array}{l}\text { Boston, } \\
\text { US } \uparrow\end{array}$ \\
\hline 6 & $\begin{array}{l}\text { Syracuse, } \\
\text { US }\end{array}$ & $\begin{array}{c}\text { Minneapolis } \\
\text { and } \\
\text { Saint Paul, US * }\end{array}$ & $\begin{array}{c}\text { Cambridge, } \\
\text { US } \uparrow\end{array}$ & $\begin{array}{l}\text { Stillwater, } \\
\text { US } \uparrow\end{array}$ & $\begin{array}{c}\text { Copenhagen, } \\
\text { Denmark }^{*}\end{array}$ \\
\hline 7 & $\begin{array}{l}\text { Boston, } \\
\text { US }\end{array}$ & $\begin{array}{l}\text { Stillwater, } \\
\text { US * }\end{array}$ & $\begin{array}{l}\text { Syracuse, } \\
\text { US } \downarrow\end{array}$ & $\begin{array}{c}\text { Paris, } \\
\text { France } \downarrow\end{array}$ & $\begin{array}{c}\text { Seattle, } \\
\text { US } \uparrow\end{array}$ \\
\hline 8 & $\begin{array}{c}\text { Philadelphia, } \\
\text { US }\end{array}$ & $\begin{array}{c}\text { Atlanta, } \\
\text { US * }\end{array}$ & $\begin{array}{l}\text { Edmonton, } \\
\text { Canada * }\end{array}$ & $\begin{array}{c}\text { Boston, } \\
\text { US } \uparrow\end{array}$ & $\begin{array}{l}\text { Boulder, } \\
\text { US } \uparrow\end{array}$ \\
\hline 9 & $\begin{array}{c}\text { Cambridge, } \\
\text { US }\end{array}$ & $\begin{array}{l}\text { Seattle, } \\
\text { US * }\end{array}$ & $\begin{array}{l}\text { Salt Lake City, } \\
\text { US * }\end{array}$ & $\begin{array}{c}\text { New York City, } \\
\text { US } \downarrow\end{array}$ & $\begin{array}{c}\text { College Park, } \\
\text { US * }\end{array}$ \\
\hline 10 & $\begin{array}{l}\text { Stanford, } \\
\text { US }\end{array}$ & $\begin{array}{l}\text { Boulder, } \\
\text { US * }\end{array}$ & $\begin{array}{l}\text { Toronto, } \\
\text { Canada * }\end{array}$ & $\begin{array}{l}\text { Rotterdam, } \\
\text { Netherlands * }\end{array}$ & $\begin{array}{c}\text { Syracuse, } \\
\text { US } \uparrow\end{array}$ \\
\hline
\end{tabular}

Note: If the ranking of a city rose, it is indicated by ' $\uparrow$ ', while a decline is indicated by ' $\downarrow$ '. When the city first appears in the rankings, it is indicated by "*'.

\subsection{Institution Level}

In general, the research levels of a certain country depend on its leading institutions [31]. To a certain extent, prominent institutions can represent a city or even a country. In our research, 878 institutions participated in international cooperation. Figure 8 shows the number of articles published by the top 15 institutions over different time spans. The United States occupied 13 of these seats. In terms of the number, the most central institutions such as Indiana University, Imperial College London and the sub center cooperation agencies such as Oklahoma State University showed opposite development laws. The former's research was more focused in the early stage, and there is now a tendency to decay, while the latter's research has been more concentrated in recent years. Some institutions had a focus on research or have no quantitative research at the outset, especially the Erasmus University; however, due to its subsequent development, it has become a central institution. Generally speaking, an institution can represent a city, Bloomington is a central city because of the contact contribution of Kelly Business School, Indiana University, and Syracuse University has made Syracuse a cooperative center. There is no institution from Paris which has become a central institution, although Paris is an important central city. That's because there are many institutions in Paris, such as Ecole des hautes etudes commerciales DE Paris (HEC), Paris Dauphine University, and École des dirigeants et créateurs d'entreprise (EDC) Paris Business School. Their collective contribution makes Paris a collaborative center. Thus, the institutions have two different ways of contributing to the cities. The first is that one or two famous educational institutions make a city a collaborative center, and such educational institutions are also central institutions such as Indiana University. The second is that a city is central, but it does not include a central institution. Instead, it is replaced by many non-central institutions, such as for Paris. 


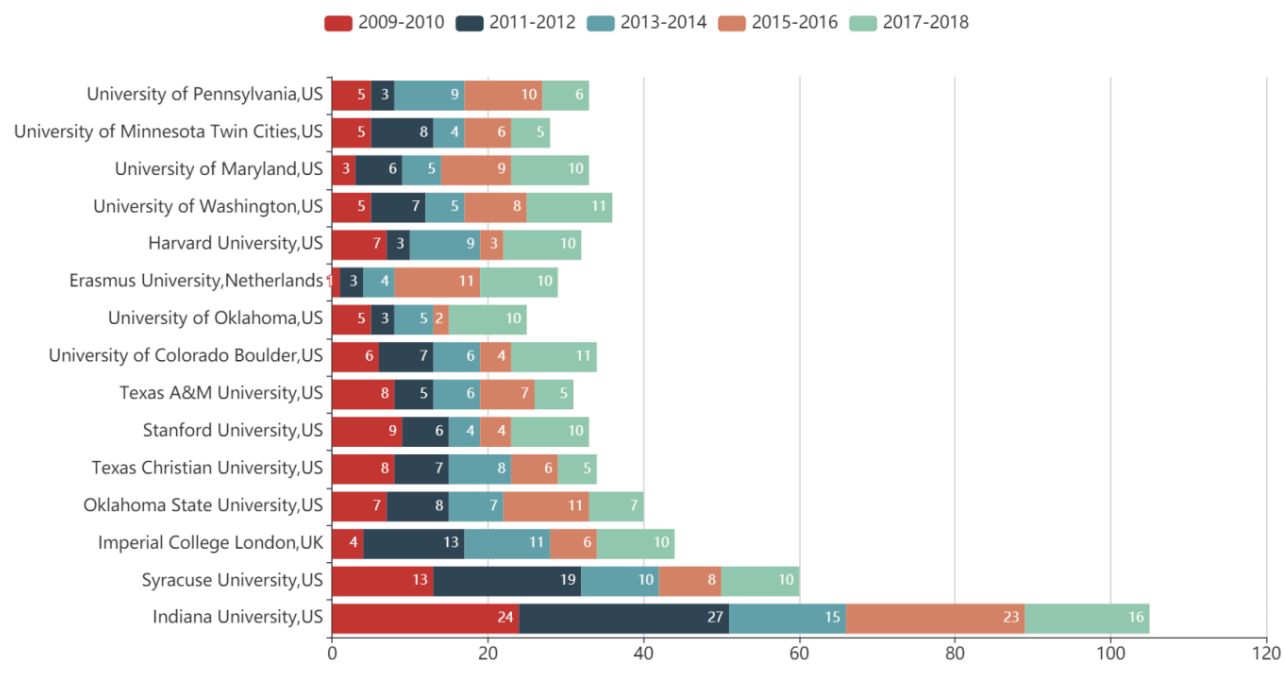

Figure 8. The top 15 institutions.

The evolution of the organizations' cooperative network is roughly the same as that of the cities (Figure 9). As time goes by, the central institutions increase, the cooperation density increases, and the existing cooperative relationships become stronger. The central institutions absorb more collaboration opportunities and make other institutions prioritize their relationships with them. In 2009, there was only one central institution, Indiana University. Subsequently, institutions such as Syracuse University, Imperial College London, and Texas A\&M University gradually grew into central institutions and established close relationships with Indiana University. Syracuse University and Indiana University established a close cooperative relationship, which corresponds to the relationship established between their respective cities, Syracuse and Bloomington. Finally, in 2018, a network of multi-cooperative center institutions was finally formed.

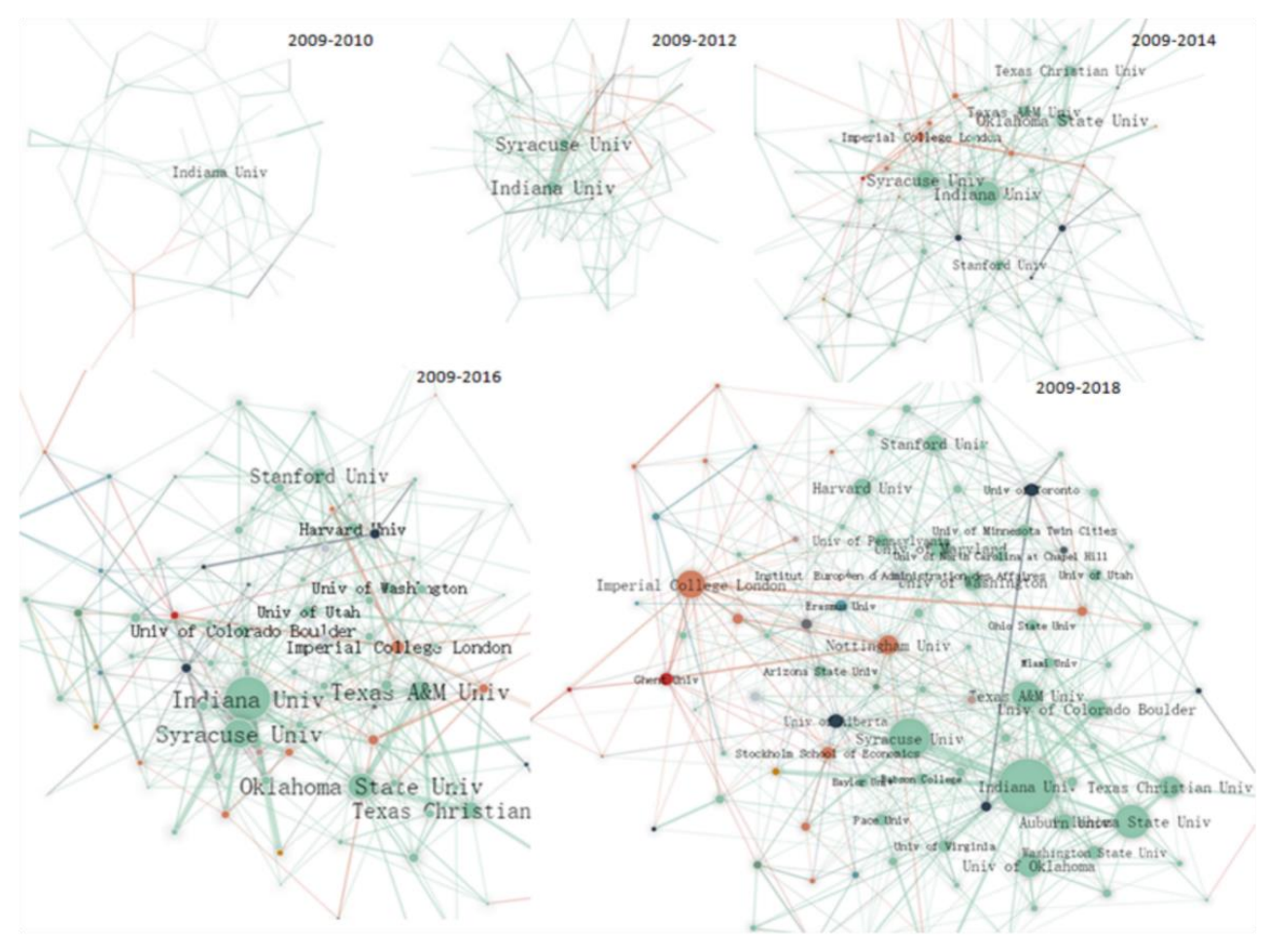

Figure 9. Evolution of collaboration networks among institutions. 


\subsection{Scholar Level}

Regardless of the country, city, or institution, the decisive factor in their importance is the scholars. Exploring the core scholars in entrepreneurship research can help researchers track research priorities and find potential partners. The distribution of paper number published by different scholars is shown in Figure 10, where the abscissa represents scholars and the ordinate represents the number of papers. It indicates an obvious long-tail distribution, where 2288 of the 3019 scholars participated in the creation of only one paper in our dataset.

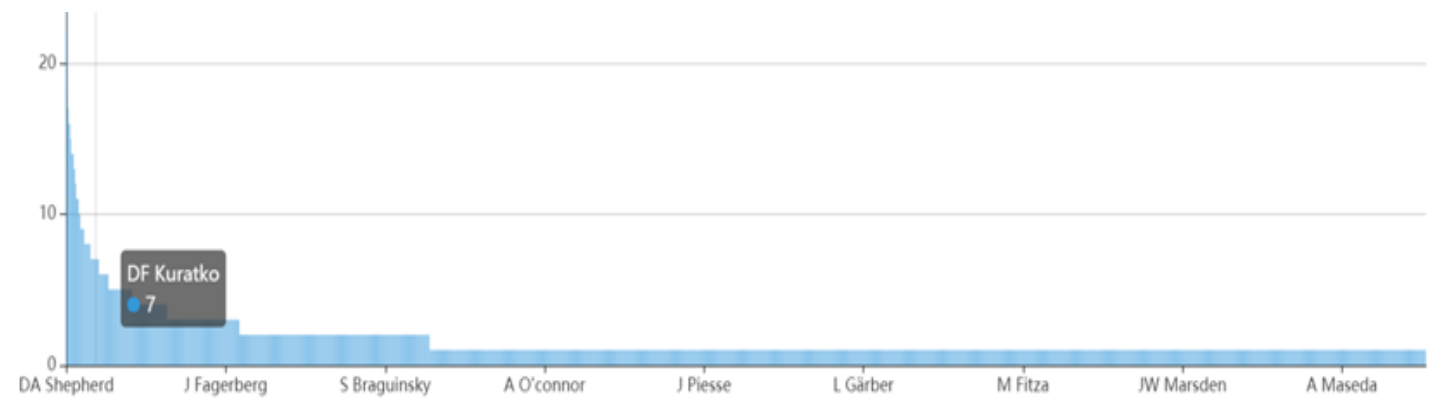

Figure 10. Number of articles per scholar.

The PII and ACI were used to explore the activities of important scholars in our dataset (Figure 11). In the figure, the sizes of the dots indicate the numbers of published papers, the green parts represent the numbers of papers for international cooperation, and the purple indicates the papers with non-international cooperation. Although these scholars published a large number of papers, they are not the first authors of all of the articles, and the quality of the articles varies. However, in general, the more articles published, the higher the $\mathrm{ACI}$ and PII. The black average line divides scholars into four regions, among which $\mathrm{HH}$-type scholars [31] publish papers with high quality and are actively involved in the creation of papers. DA Shepherd has outstanding performance even among $\mathrm{HH}$ researchers, and most of his articles have been published at Indiana University. J Wiklund, GD Bruton, and D Miller have similar behavior; they are prestigious and active researchers. As for international cooperation, most researchers except for JC Short and JS Mcmullen pay much attention to international cooperation.

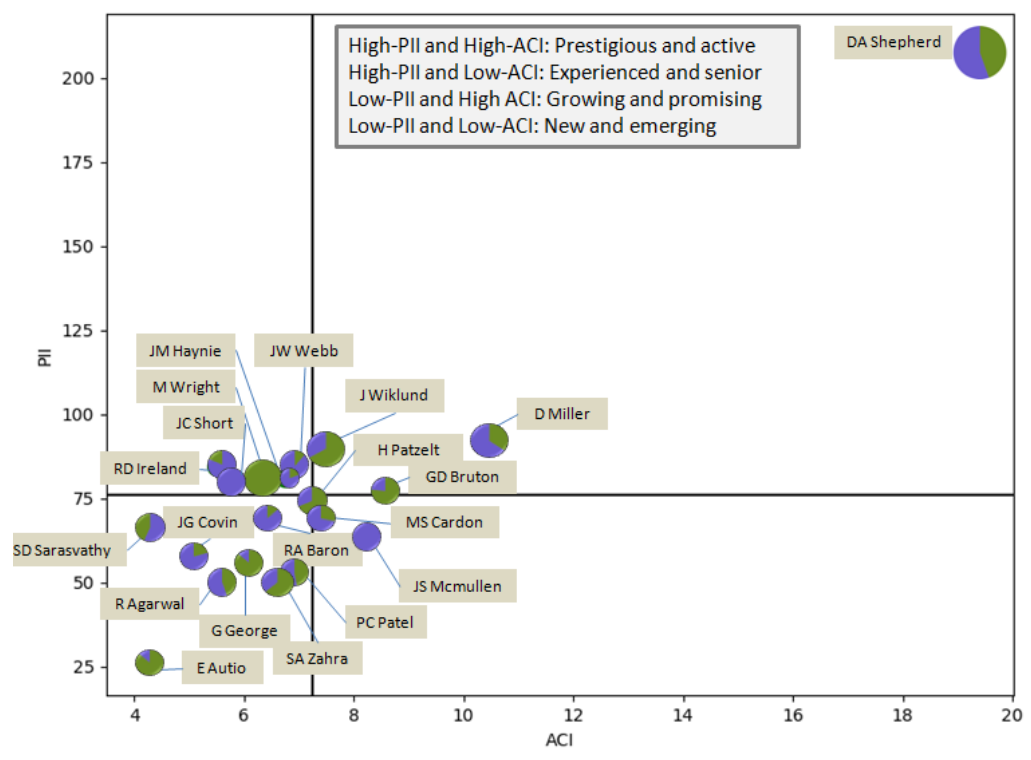

Figure 11. The activities of the top 20 scholars based on the ACI and PII. 
The evolution of the scholars' cooperative networks is similar to that of institutions and cities (Figure 12), but the initial network structure is very different. There is a clear division of the community among the researchers at the beginning; they are cluster centered on DA Shepherd, cluster centered on M Wright, and cluster centered on SD Sarasvathy. Over time, new central researchers have gradually appeared and participated in collaboration, gradually forming new communities. The cooperation within the original community has gradually strengthened, and the scope of cooperation has gradually expanded beyond the community.

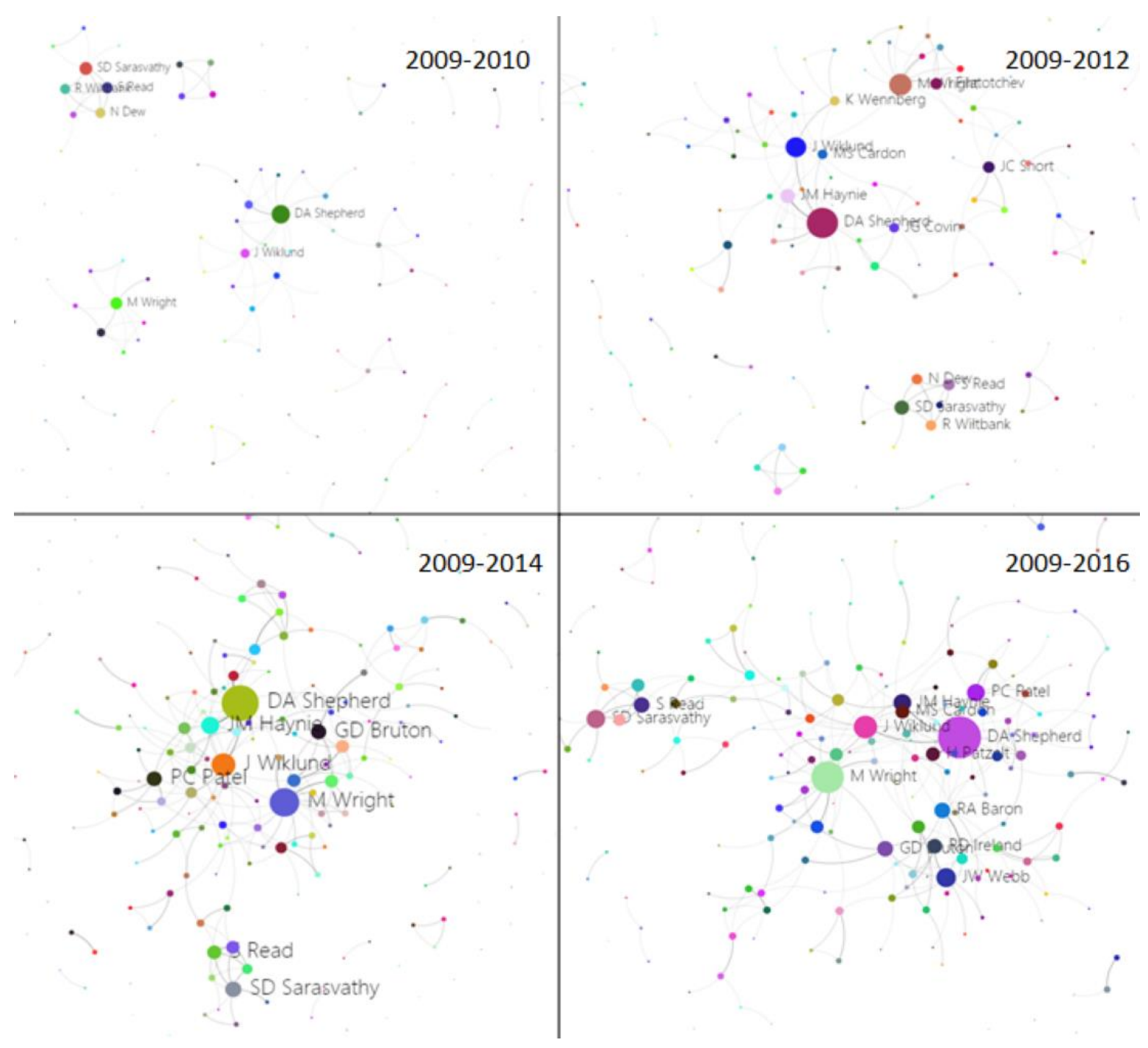

Figure 12. Evolution of collaboration networks among scholars.

Finally, as shown in Figure 13, a unified overall network has formed. Each community contains one or more central researchers, whose growth promotes the development of the community. According to the thickness of the ties, it can be seen that there is close communication among scholars in the same community, but there is very little direct, close communication between the major communities. Some of the scholars who have established contact with top scholars early on have also made remarkable achievements at the end. It can be seen that wide but not in-depth partnerships based on the central scholars are gradually taking shape. 


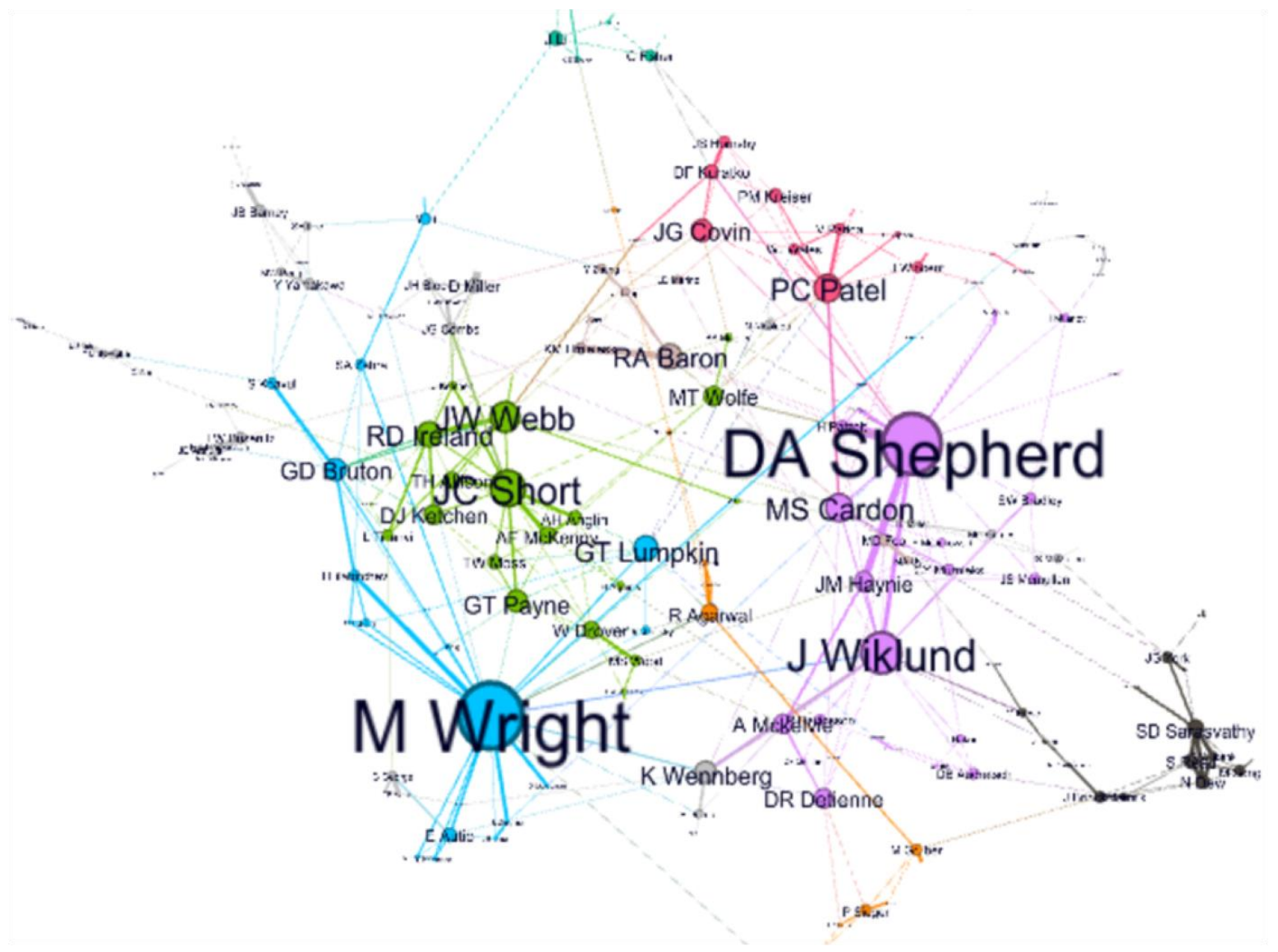

Figure 13. Community division of scholars in 2018.

\section{Conclusions}

In this paper, we used a multi-level collaborative network analysis method to study the distribution of entrepreneurial literature and the characteristics of collaboration. We paid more attention to the evaluation of the network and visualization besides statistical analysis. In addition, we also explored the positive impact of international cooperation on performance. An overview of the research results is given below.

In general, cooperation is an important measure of entrepreneurial research. Exploring international cooperation in entrepreneurial literature helps to promote the sustainable development of entrepreneurship. Although different countries, cities, and institutions show different cooperation trends, they all show the basic distribution characteristics of the core periphery, and their evolution follows the principle of priority connection. Most central countries, cities, and institutions have always maintained the vitality of research, which is directly reflected in the quantity and quality of the research results. Those peripheral countries, cities, and institutions have been constantly exploring and intensively researching.

At the country level, besides the United States and the United Kingdom, there are many center countries; they are Canada, France, Germany, Spain, Netherlands, and China and so on. American cities have not always led the pack; some emerging center cities have gradually occupied a dominant position, such as Milan, Copenhagen, and Rotterdam. China's urban performance is not outstanding probably because China's entrepreneurial research is scattered. In the evolution of collaboration, some center institutions have made a great contribution to the development of their cities and even countries, such as Imperial College London and Erasmus University. The reason why institutions from Milan, Copenhagen and other emerging cities do not perform well may be that their early research 
was insufficient. As for researchers, their number of papers obeys a long-tail distribution; only a few researchers are active in entrepreneurship research. The most prolific researchers have paid great attention to international cooperation and, as the cores, they often drive the development of the entire network.

Although our research discovers the phenomena existing in the cooperation networks and explains them reasonably, there are some shortcomings. The data used in this study were collected from some journals from the BSC database, and scope of data can be extended in future research. Furthermore, papers published in other than English can be included to expand the dataset. Therefore, in future work, we will expand the range of data and conduct a deeper study on the content of the literature, further promote entrepreneurial research, and contribute to sustainable development.

Author Contributions: The research and methodology were designed by H.X. and L.C. The data were collected by L.C. and R.S. Analysis of data and visualization was performed by R.S.

Funding: This work is funded by the National Natural Science Foundation of China (Grant Number 71620107001).

Acknowledgments: The authors are grateful for the support and contribution from graduate students of Li Cai's research group for the work of data collection, annotation and maintenance. This research is also supported from the International Innovation Team of Philosophy and Science of Jilin University.

Conflicts of Interest: The authors declare no conflict of interest.

\section{References}

1. $\mathrm{Xu}, \mathrm{J} . ;$ Chen, D.J.; Chen, W. Foreign study on entrepreneurship education based on scientometrics. Foreign Econ. Manag. 2018, 40, 64-78.

2. Chen, F.W.; Fu, L.W.; Wang, K.; Tsai, S.B.; Su, C.H. The influence of entrepreneurship and social networks on economic Growth—From a sustainable innovation perspective. Sustainability 2018, 10, 2510. [CrossRef]

3. Hall, J.K.; Daneke, G.A.; Lenox, M.J. Sustainable development and entrepreneurship: Past contributions and future directions. J. Bus. Ventur. 2010, 25, 439-448. [CrossRef]

4. Audretsch, D. Entrepreneurship research. Manag. Decis. 2012, 50, 755-764. [CrossRef]

5. Wiklund, J.; Davidsson, P.; Audretsch, D.B.; Karlsson, C. The future of entrepreneurship research. Entrep. Theory Pract. 2011, 35, 1-9. [CrossRef]

6. Ferreira, J.J.; Fernandes, C.I.; Kraus, S. Entrepreneurship research: Mapping intellectual structures and research trends. Rev. Manag. Sci. 2019, 13, 181-205. [CrossRef]

7. Baier-Fuentes, H.; Merigó, J.M.; Amorós, J.E.; Gaviria-Marín, M. International entrepreneurship: A bibliometric overview. Int. Entrep. Manag. J. 2019, 15, 385-429. [CrossRef]

8. Persaud, A.; Bayon, M.; Cartmell, S. Social entrepreneurship research: A bibliometric analysis. Acad. Manag. J. 2018, 2018, 15510. [CrossRef]

9. Peterman, N.E.; Kennedy, J. Enterprise education: Influencing students' perceptions of entrepreneurship. Entrep. Theory Pract. 2003, 28, 129-144. [CrossRef]

10. Pato, M.L.; Teixeira, A.A. Twenty years of rural entrepreneurship: A bibliometric survey. Sociol. Rural. 2016, 56, 3-28. [CrossRef]

11. Schildt, H.A.; Zahra, S.A.; Sillanpaa, A. Scholarly communities in entrepreneurship research: A co-citation analysis. Entrep. Theory Pract. 2006, 30, 399-415. [CrossRef]

12. Merigó, J.M.; Mas-Tur, A.; Roig-Tierno, N.; Ribeiro-Soriano, D. A bibliometric overview of the Journal of Business Research between 1973 and 2014. J. Bus. Res. 2015, 68, 2645-2653. [CrossRef]

13. Maritz, A. Networking, entrepreneurship and productivity in universities. Innovation 2010, 12, 18-25. [CrossRef]

14. Bornmann, L.; Leydesdorff, L. Topical connections between the institutions within an organisation (institutional co-authorships, direct citation links and co-citations). Scientometrics 2015, 102, 455-463. [CrossRef]

15. Ferreira, J.J.; Ferreira, F.A.; Fernandes, C.I.; Jalali, M.S.; Raposo, M.L.; Marques, C.S. What do we [not] know about technology entrepreneurship research? Int. Entrep. Manag. J. 2016, 12, 713-733. [CrossRef]

16. Van Raan, A.F.J. Handbook of Quantitative Studies of Science and Technology; Elsevier Science: Amsterdam, The Netherlands, 2013; pp. 19-50. 
17. Melin, G. Pragmatism and self-organization: Research collaboration on the individual level. Res. Policy 2000, 29, 31-40. [CrossRef]

18. Liu, Y.; Cheng, Y.; Yan, Z.; Ye, X. Multilevel Analysis of International Scientific Collaboration Network in the Influenza Virus Vaccine Field: 2006-2013. Sustainability 2018, 10, 1232. [CrossRef]

19. Manganote, E.J.; Araujo, M.S.; Schulz, P.A. Visualization of ranking data: Geographical signatures in international collaboration, leadership and research impact. J. Informetr. 2014, 8, 642-649. [CrossRef]

20. Coccia, M.; Wang, L. Evolution and convergence of the patterns of international scientific collaboration. Proc. Natl. Acad. Sci. USA 2016, 113, 2057-2061. [CrossRef]

21. Busenitz, L.W.; West, G.P., III; Shepherd, D.; Nelson, T.; Chandler, G.N.; Zacharakis, A. Entrepreneurship research in emergence: Past trends and future directions. J. Manag. 2003, 29, 285-308.

22. Short, J.C.; Ketchen, D.J., Jr.; Shook, C.L.; Ireland, R.D. The concept of "opportunity" in entrepreneurship research: Past accomplishments and future challenges. J. Manag. 2010, 36, 40-65. [CrossRef]

23. Busenitz, L.W.; Plummer, L.A.; Klotz, A.C.; Shahzad, A.; Rhoads, K. Entrepreneurship Research (1985-2009) and the Emergence of Opportunities. Entrep. Theory Pract. 2014, 38, 981-1000. [CrossRef]

24. Thompson, D.F.; Walker, C.K. A descriptive and historical review of bibliometrics with applications to medical sciences. Pharmacotherapy 2015, 35, 551-559. [CrossRef] [PubMed]

25. Zhang, Y.L. Analysis of the entrepreneurial research and its improvement in the application of achievements. Foreign Econ. Manag. 2010, 32, 1-7.

26. Xie, Y.; Ji, L.; Zhang, B.; Huang, G. Evolution of the scientific literature on input-output analysis: A bibliometric analysis of 1990-2017. Sustainability 2018, 10, 3135. [CrossRef]

27. Albort-Morant, G.; Ribeiro-Soriano, D. A bibliometric analysis of international impact of business incubators. J. Bus. Res. 2016, 69, 1775-1779. [CrossRef]

28. Cobo, M.J.; Martínez, M.; Gutiérrez-Salcedo, M.; Fujita, H.; Herrera-Viedma, E. 25 years at knowledge-based systems: A bibliometric analysis. Knowl.-Based Syst. 2015, 80, 3-13. [CrossRef]

29. Otte, E.; Rousseau, R. Social network analysis: A powerful strategy, also for the information sciences. J. Inf. Sci. 2002, 28, 441-453. [CrossRef]

30. Borgatti, S.P.; Mehra, A.; Brass, D.J.; Labianca, G. Network analysis in the social. Sciences 2009, 323, $892-895$. [CrossRef]

31. Butts, C.T. Social network analysis: A methodological introduction. Asian J. Soc. Psychol. 2008, 11, $13-41$. [CrossRef]

32. Newman, M.E.J. Scientific collaboration networks. I. Network construction and fundamental results. Phys. Rev. 2001, 64, 016131. [CrossRef] [PubMed]

33. Huang, Y.; Ma, J.; Porter, A.L.; Kwon, S.; Zhu, D. Analyzing collaboration networks and developmental patterns of nano-enabled drug delivery (NEDD) for brain cancer. Beilstein J. Nanotechnol. 2015, 6, 1666-1676. [CrossRef] [PubMed]

34. De Prato, G.; Nepelski, D. Global technological collaboration network: Network analysis of international co-inventions. J. Technol. Transf. 2014, 39, 358-375. [CrossRef]

35. Friedkin, N.E. Information flow through strong and weak ties in intraorganizational social networks. Soc. Netw. 1982, 3, 273-285. [CrossRef]

36. Abbasi, A.; Altmann, J.; Hwang, J. Evaluating scholars based on their academic collaboration activities: Two indices, the RC-index and the CC-index, for quantifying collaboration activities of researchers and scientific communities. Scientometrics 2010, 83, 1-13. [CrossRef]

37. Gulbrandsen, M.; Smeby, J.C. Industry funding and university professors' research performance. Res. Policy 2005, 34, 932-950. [CrossRef]

38. Myers, L.; Sirois, M.J. Spearman correlation coefficients, differences between. Encycl. Stat. Sci. $2004,12$. [CrossRef]

39. Florida, R. Cities and the creative class. City Community 2003, 2, 3-19. [CrossRef]

40. Barabási, A.L.; Albert, R. Emergence of scaling in random networks. Science 1999, 286, 509-512. [CrossRef]

(C) 2019 by the authors. Licensee MDPI, Basel, Switzerland. This article is an open access article distributed under the terms and conditions of the Creative Commons Attribution (CC BY) license (http://creativecommons.org/licenses/by/4.0/). 